\title{
Ecosystem-Based Fisheries Management, Commercial Fisheries, Marine Mammals and the 2001 Reykjavik Declaration in the Context of International Law
}

\author{
Erik Jaap Molenaar ${ }^{*}$ \\ Netherlands Institute for the Law of the Sea (NILOS). \\ Utrecht University
}

\begin{abstract}
The current global crisis in marine capture fisheries contrasts sharply with the recovery of some stocks of marine mammals. Eventually this will have to lead to a re-evaluation of the preferential treatment that marine mammals now often enjoy. The widening support for ecosystem-based fisheries management (EBFM) and the growing insight in the interactions between marine mammals and commercial fisheries are expected to influence this evaluation. This article examines the role of marine mammals in the ecosystem with special emphasis on predation on commercial fisheries. Ample attention is devoted to the definition of EBFM, its legal status and issues of implementation. The 2001 Reykjavik Declaration on Responsible Fisheries in the Marine Ecosystem is used for illustration. One of the conclusions is that sufficient scientific research is required to substantiate positive effects that pre-emptive catches of marine mammals would have for (recovering) commercial fisheries. The regulatory objectives and international legal constraints relevant to marine mammals are moreover addressed to determine if the exploitation of marine mammals could be obligatory or "necessary".
\end{abstract}

\section{Introduction}

Few will disagree that marine capture fisheries worldwide are in a sorry state. According to FAO estimates, roughly 25 per cent of the world's stocks are overexploited, 50 per cent are fully exploited and 25 per cent are under-exploited. Since 1950 global catch reports have steadily increased from around 19 million

* Email: E.Molenaar@law.uu.nl. The author would like to acknowledge the generous assistance of, and/or comments by W. Edeson, A.G. Oude Elferink, D. Pike and A. Trouwborst on an earlier version of this article. Naturally, the author remains responsible for the current text. All information found on the Internet was available at 30 May 2002.

THE INTERNATIONAL JOURNAL OF MARINE AND COASTAL LAW, Vol 17, No 4

(C) Kluwer Law International, 2002 
tons, but since the mid-1980s they have oscillated around 85 million tons. ${ }^{1}$ Some say those figures are misleading due to massive over-reporting by China and El Niño fluctuations in the Peruvian anchoveta fishery and that, consequently, the true situation is one of steadily declining global catches since the late $1980 \mathrm{~s}^{2}$ Intuitively, this latter view sounds convincing as it corresponds to numerous accounts of massive over-fishing and collapsing stocks.

Contrasting with this sad account is the fact that some stocks of marine mammals ${ }^{3}$ are showing clear signs of recovery from large-scale hunting in previous centuries and more recent pollution of the marine environment. For instance, the North-West Atlantic harp seal population was recently estimated at around 5.2 million individuals. ${ }^{4}$ Many other examples could have been mentioned here. For such stocks, extinction is clearly not an issue. This immediately raises the issue whether for such stocks the focus should continue to be on conservation exclusively or whether some harvesting, albeit in a sustainable manner, should be allowed. With respect to large cetaceans this debate is intensifying within the International Whaling Commission (IWC). ${ }^{5}$ It is not ruled out that the IWC will lift the general moratorium on commercial whaling in the near future. ${ }^{6}$ Japan, one of the most adamant pro-whaling nations, hoped this would be accomplished at the 54th Annual Meeting of the IWC (2002) in Shimonoseki, Japan, but this was not to be.

For several decades now, the IWC has been a battleground between prowhaling and anti-whaling states. ${ }^{7}$ The main cause is the diverging views on the

"The State of World Fisheries and Aquaculture, 2000", available at www.fao.org/fi, after Figure 8. D. Pauly, R. Watson and V. Christensen, "Ecological Geography as Framework for a Transition toward Responsible Fishing" in Report of the Reykjavik Conference, note below, p. 2.

3 The four classes of marine mammals are the Cetacea, which include small and large whales and dolphins, the Pinnipedia, which include seals, sea lions, walruses, etc., the Sirenia (dugongs, manatees, seacows) and the Carnivoria (sea otters).

4 "Atlantic Seal Hunt. 2002 Management Plan, Fisheries and Oceans Canada", available at www.dfo-mpo.ge.ca/seal-phoque/reports. See also the references to recoveries in J.W. Young, "Do Large Whales Have an Impact on Commercial Fishing in the South Pacific", (2000) 3 Journal of International Wildlife Law and Policy 3; and W. Aron. W. Burke and M.M.R Freeman, "The Whaling Issue", (2000) 24 Marine Policy 179-191 and 501 502.

5 This is the governing body under the International Convention for the Regulation of Whaling (Washington DC, 2 December 1946. In force 10 November 1948, 161 UNTS 72, www.iwcoffice.org).

6 The moratorium was adopted in 1982 but took effect in 1985 and 1986. IWC Resolution 2000-3 reflects awareness of this pressure by inter alia considering that "it is important for the future of the Commission that the process of completion of the RMS proceed expeditiously" (text at www.iwcoffice.org).

7 Norway is currently the only state engaged in a commercial harvest of large whales (minke whales), as it is not bound by the IWC moratorium. Japan invokes the scientific exception for considerable takes. In recent years the IWC has allocated small quotas for aboriginal subsistence whaling to states like Denmark (Greenland), the Russian Federation, St Vincent and the Grenadines and the United States (for more info see www.iwcoffice.org). Some hunting for large whales is also carried out by states non-parties to the IWC, e.g. Indonesia and the Philippines. Many more states currently allow direct takes of other marine mammals, such as small whales (Canada, Japan, Faroe Islands, Greenland, Russian Federation) and seals (Canada, Greenland, Iceland, Norway, Sweden) (see also note below and the info al www.highnorth.no). 
need for preferential treatment for marine mammals in general and large whales in particular. For some western states preferential treatment is no longer just a conservation necessity but a policy based on ethical values. "Flipper" and "Willy" simply have a lot more charisma than, say, a herring. Or in the famous words of George Orwell: "All animals are equal, but some animals are more equal than others." ${ }^{8}$ Under current general international law, however, it is largely up to each individual state to decide whether or not to hunt marine mammals within its jurisdiction. This general rule is subject to specific customary and treaty obligations, most importantly the duty to avoid over-exploitation and to prevent species from becoming extinct.' Nevertheless, certain states have even publicly announced that they would never agree on a resumption of commercial whaling within the IWC. ${ }^{10}$ Moreover, the United States has used and threatened to use trade sanctions against states that allegedly diminish the effectiveness of the IWC. This reflects a lack of respect for different ethical values and disregards the dual objectives of the IWC Convention, one of which is "the orderly development of the whaling industry". The pro-whaling camp has been criticised as well, however. The objective scientific need of Japan's scientific whaling programme, for instance, has been repeatedly questioned and there are numerous allegations of Japanese "vote-buying"." The many IWC decisions based on ethics and politics rather than science and the behaviour of the opposing camps have severely damaged the institution's credibility and legitimacy. 12

In more recent years, however, the preferential status of marine mammals is not just questioned from an ethical point of view or from one of sustainable use, but also on account of a wider recognition of the merits of ecosystem approaches and greater insights in predator-prey relationships with commercially exploited fish species. Marine mammals and humans are both significant predators in the marine environment. This is easily seen after decades of excess (human) fishing capacity on the world's fish stocks. Likewise, increased abundance of marine mammals means higher consumption of prey species. Especially when a commercial fishery also targets these species, it will not take long before the question arises whether, in

G. Orwell, Animal Farm. A Fairy Story (Penguin Books, Harmondsworth, Middlesex, 1981), p. 114. See the section headed "Marine Mammals, Regulatory Objectives and International Legal Constraints" below.

10 According to W.T. Burke, "Whaling and International Law" in G. Petursdottir (ed.), Whaling in the North Atlantic- Economic and Political Perspectives (University of Iceland. 1997) (also at www.highnorth.no), these are Australia, New Zealand and the Uniled Kingdom.

1 See the many IWC Resolutions on Japanese scientific whaling and IWC Resolution 2001-1 on transparency at www.iwcoffice.org. Also the info on vote-buying at whales.greenpeace.org, www.seashepherd.org and www.intfish.net.

12 For extensive information on the IWC and its most recent meetings see www.intfish.net. See also Aron, et al. note 4 above, and E.J. Molcnaar, Marine Mammals: The Role of Ethics and Ecosystem Considerations, 5 Journal of International Wildlife Law and Policy (forthcoming 2002). 
the face of increased abundance, preferential treatment (ban on hunting) of marine mammals is still warranted and/or affordable. ${ }^{13}$

Many states that used to ban direct takes of marine mammals may be on the verge of reconsidering this. Some already allow the culling of individual seals that interfere with fishing. ${ }^{14}$ Even the United States allows under certain conditions the intentional lethal taking of individually identified pinnipeds which are having a significant negative impact on the recovery of salmonid fishery stocks. ${ }^{15}$ Illustrative is also the favourable status of seals in the Wadden Sea, which has led Denmark, Germany and the Netherlands to reconsider their policy of rehabilitation and release. ${ }^{16}$ Once the fundamental "to kill or not to kill?" is answered in the affirmative, this may easily open the door to more extensive hunting. This situation is certainly not unique to the marine environment. The need for periodic culls to deal with excessive numbers of land mammals (e.g. deer) in nature parks is not widely criticised and acknowledgement also exists for the need for large-scale "harvesting" of kangaroos in Australia. ${ }^{17}$

For pro-whaling states the greater interest in EBFM represents welcome and dearly needed additional support for hunting the highly charismatic marine

13 Cf. P.A. Larkin, "Concepts and Issues in Marine Ecosystem Management", (1996) 6 Reviews in Fish Biology and Fisheries 139-164, at 158. Japan goes as far as presenting increased food consumption by whales as a threat to global food security (see T. Tamura, note 30 below, p. 1).

14 Denmark allows killing of individual seals that interfere with fishing in the Kattegat and Skagerrak under its Hunting and Wildlife Management Act and is currently drafting a Seal Management Plan (info kindly provided by Mr P. Uhdjibsen. Danish Ministry of Environment, 30 October 2002. The 1970 Conservation of Seals Act of the United Kingdom allows under certain conditions the killing of seals to prevent damage to fishing gear (see info at www.defra.gov.uk/paw/publications/law/default.htm). In June 2001 the Swedish Environmental Protection Agency (EPA) confirmed a National Management Plan for the Grey Seal in the Baltic, which allows under certain conditions protective hunting of 180 individuals annually as a mitigating measure against gear damage and predation on caught fish (mainly salmon). Seals are nevertheless also regarded as a (valuable) renewable natural resource and the seals' considerable annual take surely plays a role as well, even though not officially (information kindly provided by Mr P. Bjurholm, EPA, June 2002). In 2001 Finland increased the number of hunting licences for seals and continued work on a proposal for a new compensation system for damages to fishing due to seals (see Ministry of Agriculture and Forestry, Annual Report 2000, pp. 62-63 and Annual Report 2001 , p. 32 (texts at www.mmm.fi/english/organization). See the concern for predation by seals in the IBSFC Sector Report on Fisheries, note 97 below, in section "Species Interactions".

15 Section 120 of the Marine Mammal Protection Act (16 USC 1389). See (4th Quarter, 1999) MMPA Bulletin 17, 7 (www.nmfs.noaa.gov/prot_res/overview/mm.html). See also the NOAA Report (1997), note 142 below. Note that the United States used to be a contracting party to the Interim Convention on the Conservation of North Pacific Fur Seals (Washington, 9 February 1957, in force 14 October 1957, expired 14 October 1984; 314 UNTS 105; www.oceanlaw.net/ texts/index $2 . \mathrm{htm}$ ) which allowed the exploitation of fur seals.

16 See paras. 56-61 of the 1994 Leeuwarden Declaration, text at cwss.www.de. See also the Seal Management Plan 2002-2006, at section 4, text at cwss.www.de, which notes "that ethical considerations, legislation, as well as management practices differ in the three countries".

17 See D. Choquenot, J. Caughley and S. McLeod, Scientific, Economic and Social Issues of Commercial Use of Wild Animals in Australia (Canberra, Bureau of Resource Sciences, 1998), text at www.affa.gov.au. 
mammals, whether as a proper resource or to protect their commercial fisheries. It is therefore no surprise that pro-whaling states emphasise the significance of interactions between marine mammals and commercial fisheries. ${ }^{18}$ The question is, however, to what extent their point is well taken. Japan's efforts in promoting EBFM may also be motivated by legitimising the scientific value and necessity of its experimental whaling programme. ${ }^{19}$ Whether these efforts have actually supported or undermined Japan's objectives is difficult to say. During the 2002 meetings of the IWC and its Scientific Committee, the Japanese experimental whaling programme was once again subject to extensive criticism..$^{20}$

Highly illustrative of the intertwined issues of ecosystem-based fisheries management (EBFM), commercial fisheries and marine mammals is the Conference on Responsible Fisheries in the Marine Ecosystem, held in Reykjavik, 1-4 October 2001. The conference was organised by the Government of Iceland and the FAO, and co-sponsored by the Government of Norway and led to the adoption of the "Reykjavik Declaration on Responsible Fisheries in the Marine Ecosystem" on 4 October 2002. ${ }^{21}$ For reasons already alluded to, the main driving force behind the convening of the Conference were pro-whaling states. ${ }^{22}$ Participants were therefore fully aware of the role that marine mammals would play in the conference and in the drafting of the Reykjavik Declaration. ${ }^{23}$

Early drafts of the Declaration still expressly mentioned the importance of "the consumption of fish by marine mammals" but this was later replaced by "predator-prey relationships". Some delegations and environmental NGOs took the view that singling out marine mammals was inappropriate and would contribute to making them scapegoats for the current crisis in marine capture fisheries. Disagreement also existed on the use of the phrase "management of living marine resources", which was in many places eventually replaced by the

18 See, e.g. Indian Ocean Tuna Commission (IOTC) Resolution 00/02 "On a Survey of Predation of Longline Caught Fish", Appendix XIV of the Report of the Fifth Session of the IOTC (2000) (available at www.seychelles.net/iotc) and IWC Resolution 2001-9 on "Interactions between Whales and Fish Stocks" (available at www.iwcoffice.org). The convening of the Reykjavik Conference referred to in the main text below is relevant in this context as well. See the various IWC Resolutions on the subject, e.g. IWC Resolution 2001-8 (text at www.iwcoffice.org).

20 See the final Press Release at www.iwcoffice.org and the extensive discussion in the Report of the Scientific Committee (IWC/54/4, section 16, at www.iwcoffice.org/SCWEB/SCHOME.htm).

21 See the Report of the Reykjavik Conference on Responsible Fisheries in the Marine Ecosystem, (2002) FAO Fisheries Report No. 658 (FIID/R658(Tri)), and Supplement (FIID/R658 Suppl./ Suppl.(Tri)) for the abstracts of papers presented at the Reykjavik Conference. For an account of the conference see 61 Sustainable Developments 1, at www.iisd.ca. Many of the papers presented at the conference and the Declaration are available at www.refisheries2001.org. Note the conference venue and the co-sponsor. Many also pointed to the timing in relation to what was expected to be a crucial 54th IWC Meeting in Japan.

23 Note also that para. 38 of the Report of the 24th Session of FAO's Committee on Fisheries (COFI) (CL 120/7, text at www.fao.org/fi) in which the Reykjavik Conference is presented, is immediately followed by a discussion on the interaction between marine mammals and fisheries in para. 39 . 
much narrower phrase "fisheries management". 24 The pro-whaling camp may nevertheless have been modestly satisfied as it managed to retain frequent references to predator-prey relationships as well as the amusing " aware that the sustainable use of living marine resources contributes substantially to human food security, as well as dietary variety " (emphasis added). ${ }^{25}$ It is finally worth noting that the drafting of the Declaration took place in the context of the dissatisfaction of some states in the negotiation of the 2000 Honolulu Convention ${ }^{26}$ or, more in general, their dissatisfaction with the 1995 Fish Stocks Agreement. ${ }^{27}$

This article focuses predominantly on the role of marine mammals in the ecosystem and in particular their interactions with commercial fisheries. No attention is devoted to other significant non-human predators such as certain species of birds (e.g. cormorants and penguins), although these may raise similar issues, except perhaps their (even lower) appeal for human consumption. The next section starts out with some background information on marine mammals-fisheries interactions. The subsequent section ("Ecosystem-Based Fisheries Management") deals with various aspects of EBFM, including definitions, its legal status and reflections on implementation. The section following ("Marine Mammals, Regulatory Objectives and International Legal Constraints") then discusses the regulatory objectives and other international legal constraints relevant to marine mammals and the next section makes some observations on tailoring ecosystems. Some conclusions are offered at the end of the article.

\section{Marine Mammals and Commercial Fisheries}

The interactions between marine mammals and commercial fisheries can take various forms. Most relevant for this article is predation by marine mammals on commercially exploited fish or on species on which these commercially exploited fish depend. ${ }^{28}$ An average Steller sea lion in the Bering Sca, for

24 See preambular paras. 11, 12, 15, 17, 18, 21 and 22 and paras. 5 and 6 . But see preambular paras. 4,13 and 16. See also the Statements by Japan and St Lucia in Appendixes $\mathrm{J}$ and $\mathrm{K}$ to $F A O$ Fisheries Report No. 658, note 21 above, by which they abstained from joining the consensus on the Declaration, while not blocking consensus

25 Preambular paras. 13 and 16 and para. 5(b).

26. Convention on the Conservation and Management of Highly Migratory Fish Stocks in the Western and Central Pacific Ocean. Honolulu, 5 September 2000. Not in force. (2001) Law of the Sea Bulletin 45, 79-111; www.ocean-affairs.com

27 Agreement for the Implementation of the Provisions of the United Nations Convention on the Law of the Sea of 10 December 1982 relating to the Conservation and Management of Straddling Fish Stocks and Highly Migratory Fish Stocks. New York, 4 December 1995. In force 11 December 2001. (1995) Law of the Sea Bulletin 29, 25; www.un.org/Depts/los. See preambular para. 5 of the Reykjavik Declaration.

28 S.P. Northridge, "World Review of Interactions between Marine Mammals and Fisheries", (1984) FAO Fisheries Technical Paper No. 251, text at www.fao.org/documents, uses "biological interactions" in this context. D.S. Butterworth and A.E. Punt, "The Role of Harvest Control Laws, Risk and Uncertainty and the Precautionary Approach in EcosystemBased Management" in Report of the Rerkjavik Conference, note 21 above, do this as well. 
instance, is estimated to need about $6,000 \mathrm{~kg}$ of prey per year. ${ }^{29}$ There is probably also a misconception by the general public that large cetaceans only eat zooplankton such as krill. Toothed whales such as sperm whales eat large quantities of squid and the diet of baleen whales such as minke whales in North-East Atlantic waters also includes herring, capelin, cod and haddock whereas humpback whales in the North Pacific also prey on capelin, chum salmon, sand lance, Pacific herring and walleye pollock. ${ }^{30}$ A dramatic example of interactions between marine mammals and commercial fisheries are the periodic invasions of harp seals in the extreme northeast coast of Norway. The most recent one took place from 1978 to 1988, with another influx in 1995. Many seals were caught as bycatch, damage to fishing gear was extensive and seals were held responsible for the depletion of coastal fish stocks. It should not be left unmentioned that the invasions are likely to have been caused by mismanagement of the capelin and herring fisheries in the Barents Sea. ${ }^{31}$

It is also worth emphasizing here already that even if marine mammals prey on a fish species that is also of commercial interest, this does not automatically mean that a reduction in the abundance of marine mammals also guarantees an increase of that fish species. As will be discussed at more length in the section below headed "Ecosystem-Based Fisheries Management" (at subsection "Limitations of science"), the complex web of relationships in marine ecosystems makes such predictions very difficult indeed.

Other interactions besides predation include interference with fishing or fishing gear, influencing the benthic fauna (e.g. gray whales and walruses), introduction of diseases and localised impacts of faeces. ${ }^{32}$ Certain fisheries have a considerable bycatch, for instance dolphins in tuna fisheries and turtles in shrimp fisheries. More selective fishing gear, fishing practices and specific measures can reduce bycatch. In the above cases, for instance, by turtle exclusion devices (TEDs) and complex manoeuvering of purse-seine nets to let dolphins escape. ${ }^{33}$

29 Cf. A.W. Trites, "Food Webs in the Ocean: Who Eats Whom and How Much" in Report of the Revkjarik Conference, note 21 above, p. 10.

30 Cf. G.A. Vikingsson, F.O. Kapel and D.G. Pike (eds.), Minke Whales, Harp and Hooded Seals: Major Predators in the North Atlantic Ecosystem (Tromsø. Scientific Committee, The North Atlantic Marine Mammal Commission, 2000). NAMMCO Scientific Publications, Vol. 2. p. 7; T. Tamura, "Competition for Food in the Ocean: Man and other Apical Predators" in Report of the Reykjavik Conference, note above, pp. 7 and 9; and J.W. Young, note 4 above.

3 Personal communication with D. Pike.

32 S.P. Northridge, note above, and D.S. Butterworth and A.E. Punt, note 28 above, use "operational interactions" in this context, although the first classifies "diseases" under "biological interactions".

33 It is quite likely that unilateral trade sanctions imposed by the United States, even though in violation of international trade law and presumably to the detriment of third states, have contributed to the use of more selective fishing gear. See "United States-Restrictions on Imports of Tuna", Report of the GATT Panel, 20 May 1994, (1994) 33 International Legal Materials 842; and "United States- Import Prohibition of Certain Shrimp and Shrimp Products", Report of the GATT Panel, 15 May 1998, text at www.wto.org (as well as the Report of the Appellate Body and the reports of the subsequent procedures instituted by Malaysia). 
Examples of interference with fishing that come close to competition by predation are seals that raid fish-traps and predation of longline-caught fish by marine mammals such as killer whales. ${ }^{34}$ In the first instance, so-called "seal fences" can be deployed but no solution has yet been found for the second example, although experiments are under way with acoustic deterrents (pingers). ${ }^{35}$ Seals can also act as hosts to parasites, which can lead to sealworm in Atlantic cod and other fish species. ${ }^{36}$ Furthermore, high concentrations of faeces can lead to local eutrophication or contamination of shellfish beds. ${ }^{37}$

Competition for the same species is therefore not the only form of interaction between marine mammals and commercial fisheries. The economic impact of these other forms of interactions may also be taken into account when deciding on the exploitation of marine mammals. The bycatch issue, for example, is strongly influenced by the abundance of marine mammals. Higher abundance of a non-target species would allow higher "acceptable" levels of bycatch without threatening that non-target species. ${ }^{38}$ However, the fact that non-selective fishing causes unnecessary death and a waste of resources is in itself enough reason for their minimisation. But at what cost?

The issue of interactions between marine mammals and commercial fisheries is obviously not a new one. Articles 61(4) and 119(1)(b) of the LOS Convention ${ }^{39}$ already obliged states to take into account or consideration the effects of management and conservation measures on "species associated with or dependent upon harvested species". 40 The many efforts at minimising

34 Sharks are also known to target longline-caught fish.

35 See Report of the Sixth Session of the Indian Ocean Tuna Commission (IOTC) (2001), pp. 63-64. Pingers are very effective in reducing porpoise bycatch in gillnets (Report of the Working Group on Marine Mammal Population Dynamics and Habitats (2001) ICES CM 2001/ACE:01, available at www.ices.dk/reports/ACE/2001, p. 23). See also J.W. Young, note 4 above.

36 See the info in "Sealworms in the North Atlantic: Ecology and Population Dynamics", NAMMCO Scientific Publications Vol. 3, at www.nammco.no; and S.P. Northridge, note 28 above, Introduction.

37 See the NOAA Report (1997), note 142 below.

38 See H. Nijkamp and A. Nollkaemper, "The Protection of Small Cetaceans in the Face of Uncertainty: An Analysis of the ASCOBANS Agreement", (1997) 9 The Georgetown International Environmental Law Review 281-302, at 295, who describe attempts by the Advisory Committee of ICES (International Council for the Exploration of the Sea) to define acceptable bycatch levels of harbour porpoises. See also A. Gillespie, "Wasting the Oceans: Searching for Principles to Control Bycatch in International Law", (2002) 17 International Journal of Marine and Coastal Law 161-193; and Resolution 3, "Incidental Take of Small Cetaceans", adopted at the Third Meeting of Parties to ASCOBANS (2000), text at www.ascobans.org. Note that Arts. 6I(4) and 119(1)(b) of the LOS Convention (United Nations Convention on the Law of the Sea, Montego Bay, 10 December 1982; in force 16 November 1994, (1982) 21 International Legal Materials 1245; www.un.org/Depts/los) speak of "levels at which their reproduction may become seriously threatened".

39 See note 38 above.

40 W.T. Burke, The New International Law of Fisheries. UNCLOS 1982 and Beyond (Oxford, Clarendon Press, 1994), p. 58 regards associated species as including "incidental catches or bycatches" and dependent species as including "predator-prey or more distant food, or other biological relationships". 
bycatch of marine mammals are a well-known example of giving effect to this obligation, but are not discussed here as the focus is on competition for prey species. ${ }^{41}$ From this latter perspective, various states have given effect to the obligations in the LOS Convention at the national level by guaranteeing food supply for marine mammals. For example, the United States imposed a series of restrictions, including catch restrictions and area closures, on the Atka mackerel and Pacific cod and pollock fisheries in order to prevent further declines in the Steller sea lion populations in the Bering Sea. ${ }^{42}$ Likewise, the Netherlands imposes area closures and TAC reductions on several shell fisheries to ensure food supply for oystercatchers and eider ducks. ${ }^{43}$ Many more examples probably exist. ${ }^{44}$

At the regional level, states co-operating within regional fisheries management organizations (RFMOs) have progressively taken account of associated or dependent species. However, the measures taken relate predominantly to bycatch and other side effects of fishing practices (e.g. habitat destruction) and not to reserve prey species for marine mammals. A noteworthy exception is the 1980 CCAMLR Convention, ${ }^{45}$ which was developed to protect a variety of species, in particular large whales, from an uncontrolled expansion of the krill fishery in the Southern Ocean. ${ }^{46}$ The catch limits and other restrictions adopted under the CCAMLR Convention are aimed at ensuring that non-human predators are unlikely to be affected. ${ }^{47}$ Also worth mentioning are the various regional agreements for the conservation of marine mammals, which not only prohibit or regulate exploitation but also recognise the threat of bycatch in commercial fisheries. ${ }^{48}$ However, none of

41 S.P. Northridge, "An Updated World Review of Interactions between Marine Mammals and Fisheries", (1991) FAO Fisheries Technical Paper No. 251, Suppl. 1, text at www.fao.org/documents, Introduction, acknowledges that the emphasis in studies on marine mammal-fisheries interactions then carried out was on bycatch of marine mammals and less on predation by marine mammals.

42 See the motion by the North Pacific Fishery Management Council of October 2001 (info at: www.fakr.noaa.gov/npfmc, e.g. "News and Notes", October 2001, p. 1 + Attachment).

43 See note 124 below and accompanying text.

44 Note that section 3(2) of the 1991 Fisheries Management Act of Australia (Act No. 162 of 10 November 1991, text at www.austlii.edu.au/au/legis/cth/consol_act) makes the objective of optimum utilisation subject, as far as practicable, to the preservation, conservation and protection of all species of whales. However, J.L. Bannister, C.M. Kemper and R.M. Warneke, The Action Plan for Australian Cetaceans (Environment Australia, 1996) (text at www.ea.gov.au), at section 5.4.4, observe that the food consumption of whales is "rarely, if ever, taken into account, when fishery catch limits are determined". In 2002 this continued to be the case (info provided by J. Young, July 2002). However, this does not exclude that some coastal fisheries take account of food consumption by seals.

45 Convention on the Conservation of Antarctic Marine Living Resources, Canberra, 20 May 1980. In force 7 April 1982, (1980) 19 International Legal Materials 837; www.ccamlr.org.

46 See E.J. Molenaar, "CCAMLR and Southern Ocean Fisheries", (2001) 16 International Journal of Marine and Coastal Law 465-499.

47 This is inter alia to be achieved by "precautionary catch limits" and "decision rules" (see "Understanding CCAMLR's Approach to Management" at www.ccamlr.org).

48 E.g. the ASCOBANS Agreement (Agreement on the Conservation of Small Cetaceans of the Baltic and North Seas, New York, 17 March 1992, in force 29 March 1994, www.ascobans.org), the ACCOBAMS Agreement (Agreement on the Conservation of Cetaceans of the Black Sea, 
these latter regional agreements are empowered to impose catch restrictions on commercial fisheries to ensure food supply for marine mammals. ${ }^{49}$

In more recent times, the focus of attention has progressively shifted to also emphasise the impact of in particular marine mammals on commercial fisheries. ${ }^{50}$ The Preamble to the 1992 NAMMCO Agreement ${ }^{51}$ already referred to "the need to develop management procedures which take into account the relationship between marine mammals and other marine living resources". Since 1996 NAMMCO has been involved in research on the "economic aspects of marine mammals-fisheries interactions". 52 Around the same time the Joint ICES/ NAFO $^{53}$ Working Group on Harp and Hooded Seals (WGHARP) seems to have started devoting more attention to predation by seals on commercially exploited fish stocks. ${ }^{54}$ It is worth mentioning here that this roughly coincides with the collapse of the north-west Atlantic cod stocks in the early 1990s. The Working Group on Marine Mammals Population Dynamics and Habitats (WGMMPH) under the ICES Advisory Committee on Ecosystems (ACE) first met in April 2001. Among its terms of reference are the development of a database "to evaluate two-way trophic interactions between marine mammals and fisheries". 55 While these institutions are primarily concerned with the northern Atlantic, the issue of the (economic) impact of predation by marine mammals has also arisen

contd.

Mediterranean Sea and Contiguous Atlantic Area, Monaco, 24 November 1996, in force 1 June 2001, www.accobams.mc), the Wadden Sea Seal Agreement (Agreement on the Conservation of Seals in the Wadden Sea, Bonn, 16 October 1990, in force 1 October 1991, text at cwss.www.de) and the CCAS Convention (Convention for the Conservation of Antarctic Seals, London, 1 June 1972, in force 13 March 1978, www.internationalwildlifelaw.org). See also note 15 above, UN Doc. A/57/57, paras. 214-220 and other relevant regional agreements mentioned at www.oceanlaw.net/texts/index.htm. See also R.R. Churchill, "Sustaining Small Cetaceans: A Preliminary Evaluation of the Ascobans and Accobams Agreements" in A. Boyle and D. Freestone (eds.), International Law and Sustainable Development. Past Achievements and Future Challenges (Oxford, Oxford University Press, 1999), pp. 225-252.

49 Note that the Preamble to the ASCOBANS Agreement, note 48 above, is "aware of the importance of maintaining maritime activities such as fishing". However, the Preamble to the ACCOBAMS Agreement, note 48 above, is "aware that the conservation status of cetaceans can be adversely affected by factors such as reduction of food resources ".

50 See also the research cited in J.W. Young, note 4 above.

51 Agreement on Co-operation in Research, Conservation and Management of Marine Mammals in the North Atlantic, Nuuk, 9 April 1992. In force 8 July 1992, (1994) Law of the Sea Bulletin 26, 66-68; www.nammco.no.

52 See Vikingsson. et al. (eds.), note above, NAMMCO Annual Report 1999, pp. 13-14 and 129, and NAMMCO Annual Report 2000, pp. 15-16 and 169-202.

53 International Council for the Exploration of the Sea/Northwest and NAMMCO Annual Report 2001, pp. 15-16 and 191204 Atlantic Fisheries Organisation.

54 Report of the WGHARP (2000) (Doc. ICES CM 2001/ACFM:08), p. 1 (text at www.ices.dk/ products (cmdocs.asp\#ACFM). Norway, NAMMCO and the Joint Norwegian-Russian Commission requested such research.

55 Report of the WGMMPH (2001) (ICES CM 2001/ACE:01), p. 1 (text at www.ices.dk/reports/ACE/ 2001). See also p. 26, for observations on the future of the WGMMPH. The role of marine mammals in the marine ecosystem may also be addressed by the Living Resources Committee (LRC) of ICES. A "trophic level" refers to the position or level of a species in the foodweb or foodchain. 
in other international organisations, including the IOTC, IWC and the North Pacific Marine Science Organisation (PICES). ${ }^{56}$ In many cases, Japan has been instrumental in putting this issue on the agenda. Finally, the 2001 Reykjavik Conference referred to above and the recently held Expert Consultation on Ecosystem-based Fisheries Management, also in Reykjavik, in September 2002,57 must also be seen in the same context.

\section{Ecosystem-Based Fisheries Management}

As already noted, the increased attention to the interactions between marine mammals and commercial fisheries cannot be seen in isolation of the growing interest in ecosystem management and EBFM. Single-species fisheries management, viz. based on the presumption that productivity of a given species is a function only of its inherent population dynamics characteristics, is still very common today. However, as its shortcomings are fully recognised, the choice for this type of management is essentially born out of necessity. In areas with intensive fishing for different species, multi-species management was developed to take account of functional relationships between species. But from a scientific perspective even that approach was, and still is, unsatisfactory as it ignores many relevant considerations. For the purpose of this article, these considerations can roughly be divided as related or not related to fishing.

Those related to fishing include bycatch, discards, unobserved fishing mortality but also side-effects of certain fishing practices (bottom-trawling,

56 See note above and the Report of the Fourth Session of the IOTC (1999), paras. 34 and 35 and Appendix XII; Report of the Fifth Session of the IOTC (2000), paras. 75-76; Report of the Sixth Session of the IOTC (2001), paras. 101-104; all Reports available at www.seychelles.net/iotc. S.P. Northridge, note 28 above, observes that early research on interactions between marine mammals and fisheries goes back as far as 1972. See also PICES Scientific Report No. 14 (2000). "Predation by Marine Birds and Mammals in the Subarctic North Pacific Ocean", text at pices.ios.bc.ca. According to FAO Doc. RFB/II/2001/7, note 85 below, Annex 9, p. 41, research carried out by the North Pacific Anadromous Fish Commission (NPAFC) in 2000 looked at salmon as prey for large predatory fish species and marine mammals. The Sector Report on Fisheries drawn up by the IBSF, note 97 below. also foresces research on interactions between fish, marine mammals and birds (section 2.2 and Action 4). See also the joint trilateral project of the Wadden Sea states on "Feeding Ecology of Common Seals", which is mainly to provide "the necessary information, at an early state, whether seals-fishery inter-actions become evident" (Seal Management Plan 2002-2006, cwss.www.de, al section 3).

57 Info at www.fao.org/fi/NEMS/events/fisheries_events.asp. The outcome of this consultation is expected to lead to the adoption of a Technical Guideline on an Ecosystem Approach to Fisheries as a supplement to "Fisheries Management. FAO Technical Guidelines on Fisheries Management - No. 4" in the context of the implementation of the FAO Code of Conduct (see note 84, texts available at <www.fao.org//i >). The acronym EBF will not be used as "management" is inherently limited. Spanish speaking countries also had their reasons for objecting to the use of EBFM. The outcome of the consultation did not change one of the main conclusions of the 2001 Reykjavik Conference that the emphasis should be on gradually expanding the number of ecosystem considerations that should be taken into account (information kindly provided by S. Garcia, FAO, October 2002). 
dredging, dynamiting, poisoning, etc.). GESAMP ${ }^{58}$ considers the most serious non-fishing effects on the marine environment caused by human activities to be (a) the destruction and alteration of habitats (reclaiming land, deforestation, mining, coastal development, introduction of alien species, etc.), (b) pollution (in particular sewage and eutrophication) and (c) changes to hydrology and the flow of sediments (dams, large-scale irrigation, deforestation, etc.). ${ }^{59}$ The accidental introduction of exotic species, for instance by means of ballast water in merchant ships or mariculture, is another considerable threat. ${ }^{60}$ Moreover, large-scale climatic and oceanographic processes such as global warming and ENSO (El Niño-Southern Oscillation) also have an impact, although not always humaninduced. Finally, and most importantly for this paper, single- or multi-species management takes insufficient account of ecosystem processes in general, including functional relationships between species. Pursuing an ecosystem approach or EBFM means that just like any other ecosystem component, the role(s) of marine mammals must be taken into account. Very famous is the example of sea otters in the Eastern North Pacific, which were hunted down to near extinction at the end of the 19th century. As sea otters prey on urchins, and urchins feed on kelp, this resulted in a loss of crucial habitat for fish and invertebrates. ${ }^{61}$

Also illustrative of the trend to treat fisheries in a continuously wider context is the broadening scope of research undertaken by ICES. For example, the ICES Advisory Committee on Marine Pollution was replaced by the Advisory Committee on the Marine Environment (ACME). Moreover, in 2000 ICES created the Advisory Committce on Ecosystems (ACE) for the provision of scientific advice and information on the status and outlook for marine ecosystems and on the exploitation of living marine resources in an ecosystem context. ${ }^{62}$

\section{Definitions, Principles and Objectives}

In the search of definitions and objectives of EBFM, a distinction should first be made between ecosystem management and EBFM. For the latter, even though the marine ecosystem provides the context, the perspective is solely on the management of one particular use of the seas and oceans: fishing. Conversely, the former could refer to any particular use (perspective) in the abstract or all

58 GESAMP stands for: IMO/FAO/UNESCO-IOC/WMO/WHO/IAEA/UN/UNEP Joint Group of Experts on the Scientific Aspects of Marine Environmental Protection.

59 "A Sea of Troubles", GESAMP Reports and Studies No. 70 (2001), available at gesamp.imo.org, p. 2-3.

6) Ibid., pp. $12-13$.

61 Mentioned by A.W. Trites, note 143 below, p. 34, who identifies various roles for pinnipeds. See also the accompanying main text for additional examples.

62 ACE has already established various study and planning groups. For info see www.ices.dk. See also note 53 above and accompanying text. 
possible uses, but is not concerned with managing the ecosystem as such, if only because certain processes are beyond man's control. ${ }^{63}$ For instance, Canada, by means of its 1996 Oceans Act, ${ }^{64}$ pursues an ecosystem approach with regard to all marine uses. Consequently, even though the 1985 Fisheries Act of Canada ${ }^{65}$ does not expressly mention EBFM, this is implicitly required by means of the 1996 Oceans Act.

In its broadest sense, ecosystem management involves a balancing of social, economic, environmental, political and other interests. It is therefore much more multi-faceted even than the objective of sustainable development as it includes, for instance, balancing different economic interests (e.g. fishing vs. offshore mining). This article focuses mainly on EBFM, which is treated as a sectoral approach that conforms to broader societal choices. For instance, a choice between building hydro-electricity dams or maintaining traditional migration patterns of salmon is something to which EBFM has to conform, even though fisheries management authorities should point out the implications. EBFM is not regarded as exclusively science-based, but also involves the separate tasks of weighing different fisheries interests and determining the appropriate level of risk as a result of the precautionary approach. The foregoing should not imply that fisheries management authorities that pursue EBFM should not co-operate with institutions that regulate other marine uses in order to further overarching objectives.

None of the international instruments relevant to fisheries discussed below (at sub-section "Incorporation in International Instruments/State Practice") contain a definition of EBFM. The following definition is proposed by the National Research Council (NRC) of the United States:

"[A]n approach that seriously takes all major ecosystem components and services - both structural and functional - into account in managing fisheries and one that is committed to understanding larger ecosystem processes for the goal of achieving sustainability in fishery management." 66

The National Marine Fisheries Service (NMFS) of the United States does not offer a definition, but a description of EBFM, by suggesting that EBFM:

"would require managers to consider all interactions that a target fish stock has with predators, competitors, and prey species; the effects of weather and climate on fisheries biology and ecology; the complex interactions

Cf. P.A. Larkin, note 13 above, p. 146, who treats ecosystem management as more or less identical to "ocean management". c. 31, of 18 December 1996, available at laws.justice.gc.ca, preamble and sections 29-30.

65

Sustaining Marine Fisheries, Committee on Ecosystem Management for Sustainable Marine Fisheries, National Research Council (1999), www.nap.edu, p. 15. 
between fishes and their habitat; and the effects of fishing on fish stocks and their habitat". 67

Whereas a generally accepted definition of EBFM is thus not available, ${ }^{68}$ it is submitted that in contrast with single- or multi-species management, EBFM is intended to have a holistic character, aimed at capturing the "full picture" ${ }^{69} \mathrm{~A}$ conversion towards the broader perspective of EBFM effectively requires a change in mindset. It is moreover submitted that humans must also be seen as part of the ecosystem, even though unlike other living beings, they have the choice of regulating their impact on the marine environment. ${ }^{70}$ Even in the unlikely event that humans would choose to minimise direct interference (e.g. no fishing), it will be impossible to prevent any indirect effects from occurring.

Instead of attempting to come up with definitions of EBFM, however, efforts are geared towards identifying ecosystem principles, goals and policies. ${ }^{71}$ This approach seems to be inspired by the work of the Meetings of the Conference of Parties (COP) under the Biodiversity Convention. ${ }^{72}$ Whereas the Biodiversity Convention does not mention an ecosystem approach, COP-2 (1995) had already adopted the ecosystem approach as the primary framework for the analysis and implementation of the objectives of the Convention. ${ }^{73}$ COP-5 (2000) adopted Decision $\mathrm{V} / 6$ on the Ecosystem Approach. ${ }^{74}$ As a definition could not be agreed upon, COP-5 also endorsed a description of the ecosystem approach as reflecting the common understanding and recommended the application of 12 general principles of the ecosystem approach and five points for operational guidance. ${ }^{75}$ This approach was also specifically deemed relevant for marine and coastal biodiversity. ${ }^{76}$

Ecosystem-Based Fishery Management A Report to Congress by the Ecosystem Principles Advisory Panel, US Department of Commerce, National Oceanic and Atmospheric Administration, National Marine Fisheries Service, April 1999, available at www.nmfs.noaa.gov/sfa/reports.html, p. I. It is noteworthy that this description lacks any reference to non-fishery activities by humans. See also the description offered by the FAO in the World Fisheries and Aquaculture Atlas (FAO, 2001) under "Governance" and "Ecosystem Management" and the features of EBFM listed in para. 7 of Appendix H to FAO Fisheries Report No. 658, note 21 above. Cf. P.A. Larkin, note 13 above, p. 139. See also the NRC Report (1999), note 66 above, p. 15

1 The NMFS, note 67 above, the FAO, note above, and Appendix $\mathrm{H}$ to FAO Fisheries Report No. 658, note 21 above, at paras. 11-12 all take this approach. See also P.A. Larkin. note 13 above, p. 147.

72 Convention on Biological Diversity, Nairobi, 22 May 1992. In force 29 December 1993, (1992) 31 International Legal Materials 822; www.biodiv.org.

73 Decision $11 / 8$, para. 1 (UNEP/CBD/COP/2/19, p. 12; at www.biodiv.org). The objectives of the Convention are set out in Art. 1. Art. 2 defines "ecosystem" as "a dynamic complex of plant, animal and micro-organism communities and their non-living environment interacting as a functional unit"

74 UNEP Doc. UNEP/CBD/COP/5/23, p. 103; at www.biodiv.org.

75 The FAO description (note 68 above) in fact refers to these principles.

76 See Decision IV $/ 5$, al www.biodiv.org. 
The efforts on ecosystem approaches and EBFM within international institutions and individual states aim to a large extent at developing hierarchical structures with overarching or conceptual objectives at the top towards more specific and operational objectives at the base. ${ }^{77}$ Examples of overarching objectives would be "a healthy ecosystem" 78 or something like "sustainable fisheries in a healthy ecosystem". While it cannot be denied that these objectives are very vague, they nevertheless have meaning and are able to given direction. After all, the concept of sustainable development is not very specific cither but its meaning and purpose are quite clear, as well as the conflicting interests it tries to balance. ${ }^{79}$

\section{Incorporation in International Instruments/State Practice}

In view of the absence of a generally accepted definition of EBFM in relevant international instruments, it is not surprising that these instruments treat EBFM at best in an indirect fashion. Quite understandably, relatively new concepts like ecosystem management and EBFM are not mentioned in older global treaties like the LOS Convention. It is also difficult to argue that these concepts formed part of the mindset in which the LOS Convention was negotiated or that it constitutes one of its underlying objects or purposes. Or to maintain that as a "Constitution for the Oceans" which recognises that "the problems of ocean space are closely interrelated and need to be considered as a whole" ${ }^{80}$ this effectively amounts to an ecosystem approach avant la lettre. The very limited way in which ecosystems are referred to in Article 194(5) and the significantly sectoral approach of the LOS Convention support this view. ${ }^{81}$ This is not to say, however, that the LOS Convention does not oblige states to take ecosystem considerations into account, such as the need to take account of associated and dependent species and of the environmental factors that can qualify the objective of maximum sustainable yield under Articles 61 and $119 .{ }^{82}$

Even the more recent global instruments, such as Agenda 21,83 the 1995 Fish

See e.g. "Proceedings of the National Workshop on Objectives and Indicators For Ecosystembased Management", (2001) Canadian Science Advisory Secretariat (No. 2001/09), at www.dfompo.gc.ca/CSAS, pp. 9-10 and 15 .

78 E.g. the NMFS Report (1999), note above, p. 18 and Australia's 1998 Oceans Policy, pp. 12 and 19, at www.oceans.gov.au/oceans.jsp.

79 See the New Delhi Declaration on Principles of International Law Relating to Sustainable Development. adopted by the International Law Association on 6 April 2002 (see www.ila-hq.org).

80 Remarks by T.T.B. Koh, President of the Third United Nations Conference on the Law of the Sea, made at the final session at Montego Bay and the Preamble to the LOS Convention.

81 The LOS Convention treats the protection and preservation of the marine environment in a separate Part XII, which deals mainly with pollution. The conservation and utilisation of marine living resources is mainly dealt with in the zonal Parts V and VII (Arts. 61-68 and 116$120)$.

82 See also the fact that Art. 61(2) uses the term "living resources" instead of "harvested species" (as in Art. 61(3)).

83 Annex II to the Report of the United Nations Conference on Environment and Development, Rio de Janeiro, 3-14 June 1992. UN Doc. A/CONF.151/26; www.unep.org. 
Stocks Agreement and the 1995 FAO Code of Conduct ${ }^{84}$ do not explicitly refer to an ecosystem or EBFM approach, let alone contain an obligation to pursue these approaches. However, Agenda 21 effectively embraces an ecosystem approach $^{85}$ and, compared to the LOS Convention, the latter two instruments contain a far more extensive array of ecosystem considerations. ${ }^{86}$ Even if this is seen as effectively calling for or constituting an obligation to pursue EBFM, in view of the non-legally binding nature of Agenda 21 and the 1995 FAO Code of Conduct and the limited substantive scope and current status of ratification of the 1995 Fish Stocks Agreement, this presently falls significantly short of an obligation to engage in EBFM under general international law.

The one regional instrument that is widely regarded as embracing an ecosystem approach, the CCAMLR Convention, ${ }^{87}$ does not explicitly use this terminology either. Nevertheless, the objective of the Convention ${ }^{88}$ and the principles of conservation laid down in sub-paragraphs (b) and (c) of Article II $(3)^{89}$ resemble somewhat the definitions and descriptions of EBFM cited above (sub-section "Definitions, Principles and Objectives"). This notwithstanding, the efforts of the Scientific Committee to actually implement this ambitious management approach, inter alia by developing the CCAMLR Ecosystem Monitoring Program (CEMP) and giving effective content to the precautionary approach, are regarded as decisive in this respect. Despite the fact that the geographical scope of the Convention is based on the spatial dimension of the (relatively simple) marine ecosystem of the Southern Ocean, ${ }^{90}$ the difficulties

84

85 See para. 17.1 (cf. FAO Doc. RFB/1I/2001/7 ("Ecosystem-Based Management of Fisheries. Opportunities and Challenges for Coordination between Marine Regional Fishery Bodies and Regional Seas Conventions"; text at www.fao.org/documents), para. 1). Note that para. 29(d) of the Plan of Implementation of the World Summit on Sustainable Development as adopted in Johannesburg on 4 September 2002, reads "Encourage[s] the application by 2010 of the ecosystem approach, noting the Reykjavik Declaration on Responsible Fisheries in the Marine Ecosystem and decision 5/6 of the Conference of Parties to the Convention on Biological Diversity". See also para. 31(c) (text at www.johannesburgsummit.org).

86 See Art. 5 of the 1995 Fish Stocks Agreement, and Arts 6.1, 6.2, 6.4, 6.5, 6.6 and 7.2 of the FAO Code of Conduct.

87 Convention on the Conservation of Antarctic Marine Living Resources, Canberra, 20 May 1980. In force 7 April 1982, (1980) 19 International Legal Materials 837; www.ccamlr.org.

88 The conservation of Antarctic marine living resources, defined as "the populations of fin fish, molluscs, crustaceans and all other species of living organisms, including birds "(Arts. I(2) and II(1)).

89 These read:

"(b) maintenance of the ecological relationships between harvested, dependent and related populations of Antarctic marine living resources and the restoration of depleted populations to the levels defined in sub-paragraph (a) above; and

(c) prevention of changes or minimisation of the risk of changes in the marine ecosystem which are not potentially reversible over two or three decades, taking into account the state of available knowledge of the direct and indirect impact of harvesting, the effect of the introduction of alien species, the effects of associated activities on the marine ecosystem and of the effects of environmental changes, with the aim of making possible the sustained conservation of Antarctic marine living resources."

90

See Art. I and note below. 
encountered in implementing EBFM have proven considerable. ${ }^{91}$ The Scientific Committee has therefore pursued a pragmatic and gradual course by constantly broadening the knowledge base to facilitate that more and more ecosystem considerations are taken into account. ${ }^{92}$

Enclosed and semi-enclosed seas are in general very suitable for ecosystem and EBFM approaches as they often constitute large marine ecosystems (LMEs). ${ }^{93}$ The CCAMLR Convention Area was designed to coincide with an LME. ${ }^{94}$ The Baltic Sea also constitutes an LME. ${ }^{95}$ Inspired by Agenda 21, an "Agenda 21 for the Baltic Sea Region" (Baltic 21) was adopted in 1998. Baltic 21 aims at sustainable development in the Baltic Sea Region and contains overall goals and core indicators for sustainable development, specific goals and core indicators for each of the eight identified sectors, one of which is fisheries, and an Action Programme ${ }^{96}$ The International Baltic Sea Fishery Commission (IBSFC) is the Lead Party for the fisheries sector and has in that capacity drawn up the Sector Report on Fisheries, which contains an "Action Programme for the Sustainable Development of the Fishery". ${ }^{97}$ The clear commitment to pursue EBFM is inter alia reflected in this Sector Report ${ }^{98}$ and the close cooperation with ICES and the Baltic Marine Environment Protection Commission (HELCOM). This tripartite co-operation has also led to the Baltic Sea Regional Project (BSRP), which will be partly funded by the Global Environment Facility (GEF). ${ }^{99}$ The BSRP is to commence in September 2002 and aims at facilitating ecosystem-based management by these three institutions. It is worth pointing out that the IBSFC was established by the 1973 Gdansk Convention, ${ }^{100}$ which therefore even predates the LOS Convention. The participation of the IBSFC in the BSRP shows that the relatively "outdated" provisions of the Gdansk Convention ${ }^{101}$ have not been a bar to engage in modern approaches like EBFM.

Apart from the CCALMR Convention and the IBSFC, no other constituent instruments of RFMOs or the practice of the organs established under them,

${ }^{100}$ Convention on Fishing and Conservation of the Living Resources in the Baltic Sea and the Belts, Gdansk, 13 September 1973. In force 28 July 1974, www.ibsfc.org.

${ }^{101}$ However, the title of the Convention already reveals that it is not just concerned with fishing. See also the Preamble. 
embrace EBFM to a similar level. ${ }^{102}$ As regards the constituent instruments, this is hardly surprising in light of the fact that practically all were adopted prior to the negotiations on the 1995 Fish Stocks Agreement. To some extent it can therefore be expected that the management and conservation approaches and objectives, including the factors that are to be taken into account (e.g. impact on non-target, associated and dependent species), are primarily based on the relevant provisions of the LOS Convention. The conclusions of a recent study undertaken by the FAO confirm this expectation. ${ }^{103}$ Whereas most RFMOs take account of certain ecosystem considerations, for instance ecologically related species, or are engaged in relevant scientific research, this falls significantly short of an EBFM approach. ${ }^{104}$

Several RFMOs have been negotiated after the adoption of the 1995 Fish Stocks Agreement. The 2000 Honolulu Convention and the 2001 SEAFO Convention ${ }^{105}$ do not explicitly embrace EBFM either, even though they were expressly negotiated in view of the 1995 Agreement. The two treaties are difficult to compare for a number of reasons, including their different objectives. ${ }^{106}$ Even though the Honolulu Convention draws much more directly on the 1995 Agreement, ${ }^{107}$ the SEAFO Convention is certainly also a progressive instrument, here and there even showing similarities with the CCAMLR Convention. ${ }^{108}$ As

102 Although ICES has pioneered in developing ccosystem approaches and EBFM. it lacks the management functions that arc so essential for RFMOs. ICES is therefore largely exempted from making the difficult practical choices of EBFM and from justifying their financial contd.

implications. Nevertheless, as ICES gives scientific advice to various RFMOs, the influence of ICES support for EBFM should not be underestimated.

${ }_{103}$ See note 85 above. Paras. 94-99 and Annex 9. "Synthesis of [regional fishery bodies] in relation to [EBFM]" show that much still has to be undertaken before RFMOs can really be said to pursue EBFM.

104 See, for instance, the Commission on the Conservation of Southern Bluefin Tuna (CCSBT), which has a Working Group on Ecologically Related Species (ERS) since the Second Annual Meeting. See also the objective of the CCSBT Convention (Art. 3), the detinition of ecologically related species in Art. 2(a) and references thereto in Arts. 5(2) and (3), 8(1)(a), 9(2)(c) (see www.ccsbt.org). See also the NPAFC, whose Science Plan for 20012005 may extend to ecologically related species (see the definition of ecologically related species in Art. II(6) of the NPAFC Convention (see also Arts. VII(1), (3) and (4), VIII(3) and IX(1), (6), (8) and (10), and $\mathrm{X}(2)(\mathrm{b})$ and note 56 above) (see www.npafc.org).

105 Convention on the Conservation and Management of the Fishery Resources in the South-East Atlantic Ocean, Windhoek, 20 April 2001. Not in force, www.mfmr.gov.na/seafo/seafo.htm.

${ }^{106}$ For the 2000 Honolulu Convention: highly migratory fish stocks (Art. 2); for the 2001 SEAFO Convention: fishery resources (Art. 2).

107 Art. 5 is an almost verbatim copy of Art. 5 of the 1995 Agreement and Arts. 10, 12 and 13 on the functions of the Commission, the Scientific Committee and the services of scientific experts are very broadly formulated. The substance of Art. 5(e) of the 1995 Agreement is laid down in Art. $10(1)(c)$ of the Honolulu Convention.

${ }^{10 x}$ Sec, for instance, the Preamble and the definition of living marine resources in Art. $1(\mathrm{n})$, the general principles in Art. 3 (in particular para. (c) which contains the phrase "taking due account of the impact of fishing operations on ecologically related species such as seabirds, cetaceans, seals and marine turtles"); the functions of the Commission in Art. 6(3) and especially the functions of the Scientific Committee in Art. 10(4) (see the use of "living marine resources"). 
neither convention has yet entered into force, it remains to be seen to what extent the states parties and the established treaty bodies will actually fulfill the convention objectives.

Efforts are currently also under way to negotiate a South-West Indian Ocean Fisheries Commission (SWIOFC). However, these negotiations are extremely convoluted and may not even be successfully concluded. ${ }^{109}$ Initial draft texts draw on both the SEAFO and Honolulu Conventions. Finally, the 2000 Galapagos Agreement ${ }^{110}$ is a very controversial instrument, if only because it was negotiated between coastal states exclusively and took no account at all of the 1995 Fish Stocks Agreement. Whether the Galapagos Agreement will ever enter into force in its present form is not certain, but if it does it is bound to meet with much opposition. ${ }^{111}$

Finally, attention should be drawn to the North Sea, where the International North Sea Conferences, the OSPAR Commission ${ }^{112}$ and the European Community (EC) play different but not necessarily always complementary roles in the protection and preservation of the marine environment, the management and conservation of marine living resources and safeguarding biodiversity. Most significantly, the competence of the OSPAR Commission does not extend to fisheries. 13 The periodic quality status reports of the maritime area of the OSPAR Convention and its work on the protection and conservation of the ecosystems and biological diversity of the maritime area are nevertheless (perceived as) challenging this limitation of competence. Despite the efforts of all the bodies involved, this situation impedes a successful development of EBFM. In view of the opportunities for ecosystem or EBFM approaches in enclosed and semi-enclosed seas, inter alia by means of closer co-operation between RFMOs and regional marine environmental protection agreements, this is an unfortunate situation.

The progressively wider recognition of the merits of EBFM is also noticcable at the national level. For some states this is simply due to the fact that commitments made at the international level should lead to appropriate action at the national level. Some of this state practice is mentioned below by way of illustration.

109 For some information sec E.J. Molenaar, "The South Tasman Rise Arrangement of 2000 and Other Initiatives on Management and Conservation of Orange Roughy", (2001) 16 International Jounal of Marine and Coastal Law 77-124, at 109115.

110 Framework Agreement for the Conservation of the Living Marine Resources on the High Seas of the Southeast Pacific, Santiago, 14 August 2000. Not in force, www.oceanlaw.net/texts/index.htm.

${ }^{11}$ For some info see E.J. Molenaar, note 109 above, pp. 101-103 and www.oceanlaw.net/texts/ index.htm.

112 The OSPAR Commission is the main decision making body under the OSPAR Convention (Convention for the Protection of the Marine Environment of the North-East Atlantic, Paris, 22 September 1992. In force 25 March 1998, www.ospar.org) (see Art. 10).

113 See the Preamble and Art. 7 of the OSPAR Convention, Art. 4 of Annex V and the "OSPAR agreement on the meaning of certain concepts in Annex V" (Ref. No.: 1998-15.2) (all texts at www.ospar.org). Vessel-source pollution is also beyond its competence. 
Australia's 1998 Ocean Policy advocates not only ecosystem management but also more explicitly EBFM. ${ }^{14}$ Above, reference was already made to the fact that Canada's 1996 Oceans Act embraces ecosystem management even though its 1985 Fisheries Act is still based on species and populations. ${ }^{115}$ An ecosystem or EBFM approach is not incorporated in the EC Treaty ${ }^{16}$ or the secondary instruments of which the Common Fisheries Policy (CFP) is composed.117 However, in the context of the current review of the CFP, the "progressive implementation of" EBFM has now been listed among the primary objectives of the CFP. ${ }^{18}$

The Netherlands has accepted the ecosystem approach as one of the main guiding objectives in a key policy document ${ }^{119}$ and in current management. Presently, the Netherlands is in the process of defining ecosystem targets for the North Sea and making them operational. ${ }^{120}$ Care is taken to ensure that this process is closely aligned with the efforts in the context of Annex $V$ to the OSPAR Convention. ${ }^{121}$ The 1963 Fisheries Act, ${ }^{122}$ the principal instrument for fisheries management and conservation in the Netherlands, does not incorporate an ecosystem or EBFM approach. In fact, while taking account of the interests of nature conservation in the regulation of coastal and inland fisheries is obligatory, in relation to marine fisheries these interests merely "can" be taken into account. ${ }^{123}$ However, this does not exclude regulatory action under other acts or as a consequence of the CFP. The interests of nature conservation are often taken into account in the coastal and inland fisheries, for instance by the policy of area closures and downsizing the TAC on shellfish (cockles, mussels

114 Note 78 above, pp. 12 and 19.

115 See notes 64 and 65 above and accompanying text.

116 Treaty establishing the European Economic Community, Rome, 25 March 1957. In force 1 January 1958, consolidated version available at europe.eu.int/eur-lex. The EC Treaty has, inter alia, been amended by the 1986 Single European Act, the 1992 EU Treaty and the 1997 Amsterdam Treaty.

117 See, however, e.g. Arts. 6 and 174 of the EC Treaty and Art. 2 of Council Regulation (EEC) No. $3760 / 92$ of 20 December 1992, establishing a Community system for fisheries and aquaculture, (1992) OJ No. L389/1.

118 See COM(2002) 185 final, "Proposal for a Council Regulation on the conservation and sustainable exploitation of fisheries resources under the Common Fisheries Policy", Arts. 2(1) and 3(d). The Regulation will probably be adopted (with possible amendments) at the end of 2002. See also COM(2002) 186 final, "Communication from the Commission setting out a Community Action Plan to integrate environmental protection requirements into the Common Fisheries Policy", pp. 3, 5 and 8. Both documents are available through europe.eu.int/eur-lex.

119 "Nature for People, People for Nature. Policy document for nature, forest and landscape in the 21 st century", July 2000, Ministry for Agriculture, Nature Management and Fisheries; available at www.minlnv.nl/international/policy/green/pna, p. 41.

120 lbid., p. 61

121 See note 112 above, and accompanying text

122 Visserijuet 1963 of 30 May 1963. Statisblad 1963, 312, as amended.

123 See Art. 4(1) of the 1963 Fisheries Act and Parliamentary Papers, First and Second Chambers, 1999-2002, 27205, Nos. 1-14a. The relevant Articles in relation to coastal and inland fisheries are $9(1)$ and $16(2)(\mathrm{a})$. 
and mussel-seed) in order to reserve food and habitats for oystercatchers and eider ducks. ${ }^{124}$

The 1996 Fisheries Act of New Zealand ${ }^{125}$ and the 1998 Marine Living Resources Act of South Africa ${ }^{126}$ are examples of enactments which take account of critical ecosystem considerations without embracing EBFM as such. In a rather similar manner, the Sustainable Fisheries Act of the United States ${ }^{127}$ contains many provisions that contribute towards the use of ecosystem principles in fisheries management, but together they do not add up to an EBFM approach. ${ }^{128}$ However, specific projects based on EBFM have been started in various parts of the United States, including the Chesapeake Bay Program, ${ }^{129}$ and the efforts on the development of EBFM by the North Pacific Fishery Management Council (NPFMC). ${ }^{130}$

This concise overview of the status and role of EBFM in relevant international instruments and state practice shows that there is currently no firm obligation to engage in EBFM under international law. Instead, the emphasis is placed on incorporating a progressively wider range of ecosystem considerations in fisheries management. This view is also adhered to by the Reykjavik Declaration, which consistently refers to the need for sustainable fisheries management to incorporate ecosystem considerations, which "entails taking into account the impacts of fisheries on the marine ecosystem and the impacts of the marine ecosystem on fisheries". ${ }^{131}$ In fact, EBFM per se is not even mentioned once in the entire Declaration. The next subsection examines the reasons for this.

${ }^{124}$ See e.g. Structuumota Zee- en Kustvisserij (1993) (Structural Policy Document Marine and Coastal Fisheries), which formulates as policy objectives for the coastal fishery in the Wadden Sea and Eastern Scheldt: (a) the maintenance of the bird population at the average level of the 1980 s, and (b) the conservation and recovery of natural biotopes. See also Besluit vaststellen voedselreservering Oosterschelde (Decision Determination Food Reservation Eastern Scheldt; Trc $2000 / 10817$ of 16 November 2000 ).

125 Sections 8,9 and 10 of Act No. 88 of 13 August 1996, www.gplegislation.co.nz.

126 Section 2 of Act No. 18 of 27 May 1998, Government Gazette, No. 18930; text available at Www.gov.za/acts.

127 Public Law No. 104-297 of 11 October 1996, www.nmfs.noaa.gov/sfa; as incorporated in the Magnuson-Stevens Fishery Conservation and Management Act (Public Law No. 94-265; 16 USC 1801-1883; www4.law.cornell.edu/uscode.

${ }^{128} \mathrm{Cf}$, the NMFS Report (1999), note 67 above, p. 27 and A.W. Trites, P.A. Livingston, M.C. Vasconcellos, S. Mackinson, A.M. Springer and D. Pauly, "Ecosystem Considerations and the Limitations of Ecosystem Models in Fisheries Management: Insights from the Bering Sea" in 16th Lowell Wakefield Fisheries Symposium and American Fisheries Society Joint Meeting, Proceedings of Ecosystem Considerations in Fisheries Management (Anchorage, Alaska (1998), 1999), also available at www.marinemammal.org, pp. 609-619, at p. 610.

129 See the NRC Report (1999), note 66 above, p. 56 and info at www.epa.gov/r3chespk and www.chesapeakebay.net.

${ }^{130}$ For info see www.fakr.noaa.gov/npfmc.

131 10th preambular para; but see also the separate 19 th preambular para. on the impact of non-fishery activities (see also paras. 4 and 5(f)). The NRC Report (1999), note 66 above, p. 7 also propagates ecosystem consideration instead of full-scale EBFM. See also the recognition of the problems of EBFM in the FAO Atlas, note above, under "Ecosystem-based management of fisheries". 


\section{Implementing EBFM: A Reality Check}

There are a variety of reasons why preference is given to incorporating a limited number of ecosystem considerations instead of the more conceptually sound but highly ambitious EBFM approach. This subsection discusses geographical implications, limitations of science and budgetary and costeffectiveness implications. Some reflections are added on the future prospects of EBFM.

\section{Geographical implications}

A significant factor in the success of EBFM is the extent to which account is taken of the spatial dimension of ecosystems. Ideally, therefore, fisheries management authorities align their geographical competence with that of LMEs. LMEs have been defined as "regional phenomena possessed of distinguishing characteristics that differentiate them from other areas of the earth's surface, and separated from neighboring areas by physical boundaries". ${ }^{132}$ These characteristics are: unique hydrographic regimes, submarine topography and trophicallydependent populations. ${ }^{133}$ It goes without saying that even with agreement on these distinguishing characteristics, LMEs will not coincide with the partition of the oceans in maritime zones under the international law of the sea. Likewise, the provisions on the conservation and utilisation of fish stocks in the LOS Convention, the 1995 Fish Stocks Agreement and the 1995 FAO Code of Conduct take no account of the spatial dimension of marine ecosystems or LMEs, but are largely focused on the range of distribution of specific fish stocks. ${ }^{134}$ The large measure of discretion which states retain in this regard also recognises the many pragmatic and political factors that influence the spatial scope of fisheries management.

There are nevertheless cases where EBFM can more easily be based on LMEs. The CCAMLR Convention and enclosed and semi-enclosed seas, such as the Baltic, are examples that have already been addressed above (at sub-section "Incorporation in International Instruments/State Practice"). Opportunities also exist where LMEs are situated entirely within the maritime zones of a single coastal state, ${ }^{135}$ even though the difficulties of pursuing EBFM at the national level should not be underestimated either. On the whole, however, it seems that existing and future fisheries management authorities will only be infrequently

${ }^{132}$ L.M. Alexander, "Large Marine Ecosystems as Global Management Units" in K. Sherman and L.M. Alexander (eds.), Biomass Yields and Geography of Large Marine Ecosistens (Boulder, Westfield Press, 1989), pp. 339-344. at p. 339. See also the info at www.edc.uri.edu/lme.

133 Ibidem. Note that the LMEs identified at www.edc.uri.edu/lme are essentially confined to coastal areas.

134 See E.J. Molenaar, "The Concept of 'Real Interest" and Other Aspects of Co-operation through Regional Fisheries Management Mechanisms", (2000) 15 International Joumal of Marine and Coastal Lail $475-531$, at 485-489.

135 E.g. LME \#7: North-East US Continental Shelf. See also the NMFS Report (1999), note 67 above, pp. 2324. 
tailored to or re-aligned with LMEs. A more probable scenario is that RFMOs will increase co-operation with other RFMOs and other relevant institutions, such as regional marine environmental protection organisations. ${ }^{136}$

\section{Limitations of science}

Ecosystems are complex. To determine which functional relationships exist between all ecosystem components is a complicated undertaking, even for relatively "simple" marine ecosystems like in the CCAMLR Convention Area. EBFM is even more challenging, as qualitative depictions of functional relationships are complemented by a quantitative dimension that reveals the biomass (abundance) of species and the energy flows in the system. ${ }^{137}$ Moreover, to be really useful, EBFM must be able to predict the biomass of certain species as a function of certain variables, for instance human fishing. The trouble is that ecosystems are highly dynamic, like shifting mosaics, with many variables playing complex roles. Cause-and-effect relationships are frequently chaotic rather than linear. Furthermore, whereas variables such as human fishing effort may be relatively easy to predict, this is much more difficult for variables such as humaninduced changes to the environment in general or the impact of climate change. ${ }^{138}$

The shortcomings of EBFM as a predictive management tool also apply to the interactions between commercially exploited fish and marine mammals. Information is not just required on the abundance and structure of marine mammal populations but also on their consumption, inter alia indicated by stomach contents, faeces and fatty acid composition. ${ }^{139}$ These latter data are to be combined by stomach evacuation rates or energy expenditure estimates, which are complicated by opportunistic feeding behaviour, geographical and seasonal differences, age and sex differences, relation with natural mortality of prey and other (sampling) factors. So far, research carried out by individual states and institutions like the IWC, NAMMCO and PICES reveals that the currently

136 See FAO Doc. RFB/II/2001/7, note above. Most pertinent in this context are HELCOM, OSPAR and the conventions and institutions that have originated from UNEP's Regional Seas Programme. Although some of these conventions concern enclosed or semi-enclosed seas (e.g. Black Sea, Mediterranean Sea), others are based on the jurisdictional scope of coastal states (e.g. Eastern African Region) (some info at www.unep.ch/seas).

${ }^{137}$ Cf. A.W. Trites, note 29 above, p. 1 . However, Trites observes at p. 3 that energy flow food webs fail to identify which interactions are critical to the marine ecosystem.

${ }^{138}$ Cf. the NMFS Report (1999), note 67 above, p. 13; K. Richardson, "Anthropogenically-Induced Changes in the Environment: Effect on Fisheries" in Report of the Reykjavik Conference, note 21 above, p. 11; preambular paras. 14 and 17-18 and para. 5 of the Reykjavik Declaration.

139 Cf. A.W. Trites, note 29 , p. 3. The significantly lower estimates of minke whales in the Southern Hemisphere illustrate the difficulties in data collection (see IWC Resolutions 2000-4, 2001-7 available at www.iwcoffice.org). See also the request to the public to participate in a killer whale count in July 2002 to assess a possible correlation with the decline of Steller sea lions (info at www.marinemammal.org). 
available data and models are largely unable to give reliable estimates of the "take" of marine mammals. ${ }^{140}$

Very significant in our context is the difficulty in predicting that a reduction of predators that are known to prey on commercially exploited species, also leads to so-called "surplus yields" for humans. Some Japanese scientists claim that whales consume worldwide three to five times the amount taken in marine capture fisheries. ${ }^{141}$ Even if this was correct, this does not mean that without whales this amount would be available for humans, or that it would be commercially interesting. ${ }^{142}$ Changes in abundance of marine mammals may lead to trophic cascades with increased or decreased (related or inversely related) abundance of various commercially exploited species, depending on their trophic level. Likewise, predation between fish may be so substantial that decreased numbers of marine mammals does not automatically lead to higher abundance of (certain) commercially exploited species. ${ }^{143}$

\section{Budgetary and cost-effectiveness limitations}

As has become apparent from the discussion of EBFM so far, it is an extremely complex undertaking. From a scientific point of view this is no doubt a challenge, but in most cases there are also serious budgetary restrictions. ${ }^{144}$ In

${ }^{140}$ See the DFO Report (2001), note 142 below; the NOAA Report (1997), note 142 below; the Chair's Report of the 53rd IWC Meeting (2001), p. 42, available at www.iwcoffice.org; the IWC Scientific Committee will convene a meeting in La Jolla, end June 2002. NAMMCO Scientific Publications Vol. 2, note 30 above, p. 7; NAMMCO Annual Report 2000, pp. $15-16$ and 196 197; Report of the Ninth Meeting of the NAMMCO Scientific Committee (2001), pp. 3-7; Press Release of the 11 th Meeting of the NAMMCO Council (2001) (text at www.nammco.no); PICES Scientific Report No. 14, note 56 above, pp. 3-4. In June 2002, in La Yollen, the US, the IWC Scientific Committee convened pursuant to IWC Resolution 20019 a workshop on methodological modelling to examine interactions between whales and fish stocks. At the time of writing a report was not yet available.

141 E.g. T. Tamura, note 30 above, p. 1.

142 C. . P. Johnston and D. Santillo, "Whales in Competition with Commercial Fisheries: A Modern Myth Based on Pseudo-Science" (Greenpeace International, May 1999), available at whales.greenpeace.org; J.W. Young, note 4 above; and S.P. Northridge, note 28 above, Conclusions. D.S. Butterworth and A.E. Punt, note 28 above, p. 5, observe that despite the fact that fur seals prey on hake off South Africa, a seal cull was estimated to actually decrease, not increase, the catches of the hake fishery. See also the (2001) Report of the Eminent Panel on Seal Management, Department of Fisheries and Oceans Canada, text available at www.dfompo.gc.ca/seal-phoque/reports, pp. vi, viii and Appendix 5 where the panelists were unable to agree on the gravity of the impact of seal predation on commercially exploited stocks, especially the Atlantic cod stock. "The Investigation of Scientific Information on the Impacts of California Sea Lions and Pacific Harbor Seals on Salmonids and on the Coastal Ecosystems of Washington, Oregon, and California", US Dep. Commer., NOAA Tech. Memo. NMFSNWFSC-28 (1997), available at www.nmfs.noaa.gov/prot_res/overview/publicat.html\#other, had a similar outcome.

${ }^{143}$ Cf. A.W. Trites, "The Role of Pinnipeds in the Ecosystem" in G. Stone, J. Goebel and S. Webster (eds.), Pinniped Populations, Eastern North Pacific: Status, Trends and Issues (1997), pp. 31-39, also available at www.marinemammal.org, pp. 34-35.

144 See also Decision VI/12 on the Ecosystem Approach, adopted at COP-6 of the Biodiversity Convention (text at www, biodiv.org). 
this context it should be noted that the pioneering efforts in ecosystem management by CCAMLR in the Southern Ocean were in no small part facilitated by the special status of Antarctica and its surrounding waters. The agreement to disagree on their legal status facilitated a special emphasis on scientific research and conservation and a 50-year moratorium on mineral resource activities. ${ }^{145}$ The reality is that most developing states are unable to do even the most basic research on stock assessments, let alone the sophisticated research needed for EBFM. ${ }^{146}$

From the perspective of cost-effectiveness, comprehensive EBFM may be so costly that economically it may be more sound not to engage in fishing at all. Pursuing conservative single-species management may be more cost-effective than the fine-tuning that can be accomplished through EBFM. The potential benefits of EBFM are very likely to be much smaller than the more straightforward solutions to the main problems currently faced by global marine capture fisheries. At the 2001 Reykjavik Conference it was cynically mentioned by one participant that the three main solutions to these problems were: (1) reduce capacity, (2) reduce capacity and (3) reduce capacity. ${ }^{147}$ It is noteworthy that the Reykjavik Declaration refers to the need to reduce capacity and for incentives that encourage responsible fisheries at the very outset, in paragraph 2. ${ }^{148}$ However, none of these considerations are valid excuses for fisheries management authorities to ignore the complexity of functional relationships and ecosystems altogether and to abstain from taking the steps towards EBFM that are already within reach.

\section{Future prospects of EBFM}

In view of the current preference for incorporating ecosystem considerations into fisheries management above full-scale EBFM, what are the future prospects for EBFM? In the near future it is expected that EBFM will merely be used to complement single- or multi-species management. From a scientific perspective, however, ecosystem models are very useful and act as vehicles for fostering multidisciplinary management and research. ${ }^{149}$ The main message conveyed by the practice of CCAMLR, however, is that EBFM is a goal that may become attainable by gradually expanding the scope and number of ecosystem

${ }^{145}$ See Arts. II and III of the Antarctic Treaty, Art. II of the CCAMLR Convention and Arts. 7 and 25(2) of the Madrid Protocol.

${ }^{146}$ See preambular para. 20 and para. 7 of the Reykjavik Declaration.

147 See also paras. 5 and 8 of Appendix H to FAO Fisheries Report No. 658, note 21 above.

${ }^{148}$ This view is also taken in the NRC Report (1999), note 66 above, pp. 5-7. See also the OECD Report (2000), "Transition to Responsible Fisheries: Economic and Policy Implications", readonly version at www.oecd.org, which expressly touches on overcapacity and subsidies in the Statement by the Committee for Fisheries, pp. 11-12.

149) Cf. A.W. Trites, et al., note 128 above; P.A. Larkin, note 13 above, p. 153. 
considerations. ${ }^{150}$ The outcome of the recently held Expert Consultation on EBFM may shed more light on this matter. ${ }^{151}$

\section{Marine Mammals, Regulatory Objectives and International Legal Constraints}

The basic rights and obligations of states on the use and conservation of marine mammals under current international law are largely laid down in the LOS Convention. A right of exploitation can be based on a coastal state's sovereignty within its internal waters, territorial sea or archipelagic waters, its sovereign rights over the living resources in the exclusive economic zone (EEZ) or, for all states, the freedom of fishing on the high seas. ${ }^{152}$

These rights are subject to a large number of obligations. None of these obligations expressly apply to the territorial sea or archipelagic waters, even though similar duties may exist under customary international law, inter alia through the duty to avoid transboundary harm. Articles 61 and 62 of the LOS Convention oblige states to avoid over-exploitation and to promote the objective of optimum utilisation with respect to the living resources of the EEZ. The duty to avoid over-exploitation also encompasses the duty to avoid extinction of species. ${ }^{153}$ With respect to the high seas, section 2 of Part VII of the LOS Convention, on "Conservation and Management of the Living Resources of the High Seas", does not contain a general obligation to promote optimum utilisation of all marine living resources. Instead, the emphasis lies on conservation and, by implication, avoiding over-exploitation. ${ }^{154}$ As these provisions concern "living resources", marine mammals are covered as well. However, Article 65 on "Marine Mammals" contains the following lex specialis:

${ }^{150}$ Cf. the NRC Report (1999), note 66 above, p. 6; para. 16 of Appendix H to FAO Fisheries Report No. 658, note 21 above; S. Mathew, "Small-Scale Fisheries Perspective on an Ecosystems-Based Approach to Fisheries Management" in Report of the Reykjavik Conference, note 21 above, p. 14, who promotes a "crossword approach" that first tackles easy management issues before harder ones.

${ }^{151}$ See note 57 above.

152 Arts, 2(1), 56(1)(a), 87(1)(e) and 116 of the LOS Convention.

153 Relevant duties are laid down in the Biodiversity Convention and the CITES Convention (Convention on International Trade in Endangered Species of Wild Fauna and Flora, Washington DC, 3 March 1973. In force 1 July 1975, text at www.cites.org). The conservation of biological diversity is inter alia required by Arts. 1 and 5 of the Biodiversity Convention, even though Art. 1 is worded in general terms and qualified (see also Art. 3). "Biological diversity" encompasses diversity within species (incl. genetic diversity), between species, of ecosystems and habitats (Art. 2). The CITES Convention requires contracting parties to prohibit or strictly regulate trade in (potentially) endangered species (Arts. II(4) and VIII). The Convention's objectives can be inferred from the Preamble (avoiding over-exploitation through international trade) and Art. II (avoiding extinction).

${ }^{154}$ See the references in Arts. 117 and 119 to conservation exclusively and in Art. 118 together with management (even the emphasis in Art. 118 is more on conservation). See also note 156 below. 
"Nothing in this Part restricts the right of a coastal State or the competence of an international organization, as appropriate, to prohibit, limit or regulate the exploitation of marine mammals more strictly than provided for in this Part. States shall cooperate with a view to the conservation of marine mammals and in the case of cetaceans shall in particular work through the appropriate international organizations for their conservation, management and study."

Article 120 provides that "Article 65 also applies to the conservation and management of marine mammals in the high seas". Article 65 consists of two sentences that deal with separate issues. The first sentence ensures by means of the phrase "more strictly" that the obligation to promote optimum utilisation does not apply to marine mammals in the EEZ or the high seas. In fact, it recognises that coastal states or international organisations could prohibit the exploitation of marine mammals altogether. However, if international organisations would actually do this, this would not necessarily be legally binding for all states or all states parties to the LOS Convention.

The second sentence of Article 65 obliges states ${ }^{155}$ to co-operate "with a view to the conservation of marine mammals". Worth noting is that Articles 63-67 and 116(b) establish obligations to co-operate in relation to transboundary stocks of living resources. In that regard, marine mammals would be covered by way of Article 63 and, for some species, Article $64 .{ }^{156}$ The obligation to cooperate in Article 65 thus either strengthens these obligations or complements them in relation to non-transboundary stocks of marine mammals. The emphasis on conservation in Article 65 does not mean that there can be no exploitation. However, the reference to the "appropriate international organizations" raises the issue whether states can engage in exploitation of marine mammals without co-operating with international organisations whose competence would in principle extend to these species. As this issue is currently most pertinent with respect to the IWC, does the duty to co-operate in Article 65 mean that states cannot engage in the exploitation of large cetaceans without some form of co-operation with the IWC? ${ }^{157}$ While there is some

155 The fact that the second sentence of Art. 65 uses "States" whereas Art. 64 uses "The coastal State and other States whose national fish ", appears to reflect a need to ensure that the range of involved states is broader than merely coastal states and (high seas) fishing states (see also Art. 63(2)).

156 See points 15 and 17 of Annex I to the LOS Convention. Art. 64(1) also contains a duty to promote the objective of optimum utilisation (both within and beyond the EEZ) linked to the duty of co-operation. However, the phrase "Nothing in this Part" at the outset of Art. 65 ensures its status as a lex specialis. even in view of para. (2) of Art. 64.

157 Note that Art. 8(3) of the 1995 Fish Stocks Agreement stipulates that relevant states "shall give effect to their duty to cooperate by becoming members of such organization or participants in such arrangement, or by agreeing to apply the conservation and management measures established by such organization or arrangement". 
support for an affirmative answer to this question, ${ }^{158}$ there are a variety of other reasons why states choose not to "go unilateral" or in fact choose not to engage in hunting for marine mammals at all, such as pressure by other states, NGOs or consumers. ${ }^{159}$

Articles 65 and 120 of the LOS Convention thus ensure that the objective of optimum utilisation does not apply to marine mammals and thereby relieve states from the obligation to exploit marine mammals themselves or from authorising other states to do so. ${ }^{160}$ This undoubtedly constitutes a difference between marine mammals and other marine living resources. Its rationale seems primarily based on the troublesome status of many or most of the world's stocks of marine mammals at the time when the LOS Convention was negotiated (19731982). To a lesser extent it probably also acknowledges that some states take the view that the distinction between marine mammals and other marine living resources is more fundamental. However, no support exists for the view that the international community of states at that time agreed that such a distinction would have implications for the right of exploitation. State practice since then has also not established a rule of customary international law to that effect. The reality is, however, that marine mammals enjoy a preferential status in many states and that these states have subsequently ensured that this also occurred in international organisations and instruments. In this context, it is not surprising that states supporting the exploitation of marine mammals feel compelled to justify this, irrespective of their right to engage in exploitation in their own maritime zones and on the high seas. ${ }^{161}$

One fundamental point that even states supporting preferential treatment for marine mammals must acknowledge is that marine mammals do play a role. In areas where all fish stocks are fully or over-exploited, large populations of marine mammals may deteriorate the status of those fish stocks. ${ }^{162}$ The effect of catch restrictions on commercial fisheries could then be negated by an increased

${ }^{158}$ E.g. the fact that the Norwegian quotas for minke whales take account of the work of the Scientific Committee of the IWC, the continued membership of Japan and the recent efforts (2001 and 2002) of Iceland to become a member of the IWC again. In light of the duty to cooperate under Art. 65 of the LOS Convention, it is interesting to note that the reservation in the 2002 Icelandic application for membership contained the statement that "Iceland will not authorize whaling for commercial purposes by Icelandic vessels while progress is being made in negotiations within" the IWC on the Revised Management Scheme.

${ }^{159}$ See W.T. Burke, The New International Law of Fisheries. UNCLOS 1982 and Beyond (Oxford, Clarendon Press, 1994), pp. 286-287 and 295.

${ }^{160}$ This authorisation would arise from the duty to give access to the surplus in the total allowable catch (Art. 62(2)).

161 E.g. the 13th preambular para. of the Reykjavik Declaration (see the main text accompanying note above). Para. 17.73 of Agenda 21 is often also cited for this purpose.

162 These questions were at the heart of the NOAA Report (1997), note 142 above and the DFO Report (2001), note 142 above. In the Baltic Sea, fears exist that the abundance of grey seals are frustrating the IBSFC Salmon Action Plan 1997-2010 (see also note 14 above). 
take by marine mammals. Arguably, in order to rebuild or protect fish stocks from further deterioration, a pre-emptive (anticipatory) catch of marine mammals may "not be a bad idea". The amount of scientific evidence needed to prove that pre-emptive catches indeed improve the status of fish stocks or prevent them from further deterioration would nevertheless be of crucial importance.

Human activities are the main, if not only, reason for the current deplorable status of fish stocks worldwide. Marine mammals should therefore not be treated as scapegoats for human failure. However, human efforts to rebuild fish stocks may in part be diminished due to predation by marine mammals. Similarly, the current status of fish stocks is not primarily caused by illegal, unreported and unregulated (IUU) fishing, but it cannot be denied that the phenomenon is presently a contributing factor. Likewise, aboriginal whaling was also not responsible for the near-extinction of many species of marine mammals, but for some species it may lead to that now. Rather than using marine mammals as scapegoats, all predators, human and non-human, must be acknowledged as currently (potentially) contributing to or prolonging the problem. One could also see it as an issue of shared responsibility, although marine mammals are of course unable to accept that responsibility themselves and the consequences are much more far-reaching for them. This clearly raises philosophical questions on the role of humans on earth.

Are pre-emptive catches of marine mammals under the circumstances sketched above merely not a bad idea? Could there not also be circumstances where it would be obligatory to do so under international law? Provided, of course, that sufficient scientific evidence supports the effectiveness of preemptive catches. The main situation that springs to mind is where marine mammals dominate ecosystems to the extent that other (populations of) species are under threat of extinction, either due to predation or due to side effects (e.g. diseases or eutrophication). One line of reasoning would be that the phrase "Nothing in this Part" at the outset of Article 65 allows states to abstain from taking any action.

Two observations can be made here. Firstly, Article 65 was drafted when the abundance of most stocks of marine mammals was abominably low and the negotiators are not likely to have contemplated situations of high abundance. It is in this light that the obligations under Articles 61(4) and 119(1)(b) of the LOS Convention must be interpreted. These provisions oblige coastal states and high seas fishing states when taking management and conservation measures, "to take into consideration the effects on associated with or dependent upon harvested species with a view to maintaining or restoring populations of such associated or dependent species above levels at which their reproduction may become seriously threatened". In relation to marine mammals, this would inter alia cover situations such as bycatch and shortage of prey. The fact that both provisions refer to "harvested species" indicates that a situation in which species exempt from exploitation would have a 
problematic impact on associated or dependent species was not envisaged. ${ }^{163}$

Secondly, at any rate this phrase does not exclude the applicability of other rules of international law, including those in other parts of the LOS Convention. The relevant obligations to avoid species from becoming extinct under the Biodiversity Convention and the CITES Convention ${ }^{164}$ and the obligation under Article 194(5) of the LOS Convention "to protect and preserve rare or fragile ecosystems as well as the habitat of depleted, threatened or endangered species and other forms of marine life" could be mentioned here. It would appear to this author that such obligations override the large discretion of states under Articles 65 and 120 . Worth noting is that the United States also accepts this view; at least within its national sphere. 165

A somewhat different situation occurs where large numbers of marine mammals cause severe transboundary effects to ecosystems or living resources in the maritime zones of other states, or on the high seas. The effects may be somewhat similar to those caused by over-exploitation of transboundary fish stocks. In view of the strong wording of Article 65, however, the superiority of the interests of other states is not so evident in comparison with the obligations on extinction of species.

Finally, some discussion is warranted on the relevance of the precautionary approach, which has been developed to prevent damage in situations of scientific uncertainty. The precautionary approach has been laid down in a large number of international instruments and is also regarded as having customary status. ${ }^{166}$ Article 6(2) of the 1995 Fish Stocks Agreement requires states to "be more cautious when information is uncertain, unreliable or inadequate" and that the "absence of adequate scientific information shall not be used as a reason for postponing or failing to take conservation and management measures". ${ }^{167}$ While the conceptual soundness of the precautionary approach is difficult to contest,

${ }^{163}$ However, S.N. Nandan, S. Rosenne (vol. eds.) and M.H. Nordquist (ed.-in-chief), United Nations Convention on the Law of the Sea 1982, A Commentary, Volume II (Dordrecht/Boston/ London, Martinus Nijhoff Publishers, 1993), p. 664 observe that "The provisions of article 65, therefore, as lex specialis may supersede the requirements of article 61, paragraph 4" (see also p. 611). W.T. Burke, note 159 above, p. 267 observes that "complete prohibitions on the harvest of marine mammals is within coastal authority under contemporary international law". However, he may not have contemplated the negative impact of high abundance of marine mammals either. See also p. 290.

164 See note 153 above.

165 The study undertaken in the NOAA Report (1997), note 142 above, was called for in section 120(f)(1)(A) of the MMPA (16 USC 1389) and was to "determine whether California sea lions and Pacific harbor seals a) are having a significant negative impact on the recovery of Salmonid fishery stocks which have been listed as endangered species or threatened species under the Endangered Species Act of 1973 (16 USC 1531 et seq.), or which the Secretary finds are approaching such endangered species or threatened species status; or b) are having broader impacts on the coastal ecosystems of Washington, Oregon, and California".

$166 \mathrm{Cf}$. A. Trouwborst, Evolution and Status of the Precautionary Principle in International Law (The Hague, Kluwer Law International, 2002). See e.g. Principle 15 of the 1992 Rio Declaration on Environment and Development, available at www.unep.org.

${ }^{167}$ See also Annex II. 
considerable difficulties remain in its practical implementation. ${ }^{168}$ What standard of scientific evidence or uncertainty is needed to justify what type of measures, if any, and where lies the burden of proof? The precautionary approach should not be interpreted as meaning that fishing cannot commence or continue until no scientific uncertainties remain, because that will surely never happen. The level of scientific uncertainty on various biological aspects of marine mammals is probably higher even than for most fish species. This notwithstanding, given the highly politicised nature of the current IWC, it is not unlikely that scientific uncertainty has been unreasonably used to reject the lifting of the moratorium on commercial whaling. ${ }^{69}$ States like Japan may therefore be concerned that the precautionary approach will lead to an excessively conservationist attitude with obvious implications for exploitation. ${ }^{170}$ Indications moreover exist that several states are in particular fearful of the trade implications of the misuse of the precautionary approach. ${ }^{171}$

When catch restrictions on fish stocks are introduced or increased as a consequence of the precautionary approach, it should be borne in mind that this benefits other predators for the same stocks as these are free from regulatory restrictions. The effect of applying the precautionary approach may then be negated. Especially where the pressure on species or ecosystems approaches the risk of extinction, the precautionary approach may therefore also require the exploitation of marine mammals, or that catches already in place are enlarged. ${ }^{172}$ Whether or not as part of the precautionary approach, hunting marine mammals could in that case be regarded as a form of purchasing insurance. ${ }^{173}$

${ }^{168}$ See, inter alia, W. Edeson, D. Freestone and E. Gudmundsdottir (eds.), Legislation for Sustainable Fisheries. A Guide to Implementing the 1993 FAO Compliance Agreement and 1995 UN Fish Stocks Agreement (Washington DC, The World Bank, 2001), pp. 30-33.

169 This is just one aspect of the debate surrounding the requirement that amendments to the Schedule to the IWC Convention "shall be based on scientific findings" (Art. V(2)(b) of the IWC Convention), which has inter alia led to the questioning of the legality of the Southern Ocean Sanctuary.

${ }^{170}$ This may explain why A. Kanehara, "A Critical Analysis of Changes and Recent Developments in the Concept of Conservation of Fishery Resources on the High Seas", (1998) The Japanese Annual of International Law 41,129, is so critical of the precautionary approach (see especially p. 12).

171 See e.g. Who to Blame 10 Years after RIO? The Role of the USA, Canada, and Australia in Undermining the RIO Agreements (Greenpeace International, 2002), available at archive greenpeace.org/earthsummit/documents.html. See also paras. 45(e) and 45(e.alt) of the last Draft to the WSSD Plan of Implementation (A/CONF.199/PC/LS/Rev.1), which stipulated that the application of the precautionary approach should not be used as a "disguised barrier to trade" or "for protectionist purposes". The text eventually adopted (para. 103(f)) does not contain any of these references.

172 It is not correct to regard the precautionary approach exclusively in terms of obligating states not to engage in certain activities. Action can also be required. See for instance Biodiversity Convention Decision VI/23 on "Alien Species that Threaten Ecosystems, Habitats or Species", which notes in "Guiding principle 1: Precautionary approach" that "The precautionary approach should also be applied when considering eradication" (text at www.biodiv.org). This is merely an example and does not suggest that the situation described in the main text is similar to that of alien species.

${ }^{173}$ See the observations on insurance in the NFMS Report (1999), note 67 above, p. 19. 


\section{Tailoring Ecosystems}

Could hunting for marine mammals also be "necessary" in cases where it is not obligatory? Necessity is largely a subjective notion, determined as it is by individual preferences and interests. To keep these in check, the international community developed and agreed the regulatory objectives and international legal constraints discussed in the previous section. As long as these are observed, states can adjust the ecological balance to their needs, for instance by imposing restrictions on fisheries to protect marine mammals or vice versa. Such choices are not fundamentally different from choices on other uses of the (marine) environment in view of the overarching objective of sustainable development. In the context of EBFM, the overarching objective would be something like: the need for sustainable fisheries in a healthy ecosystem.

Whereas tailoring ecosystems to what is perceived as necessary is not inconsistent with international law or the objective of sustainable development, win-win situations are scarce. Conflicting interests and uses have to be resolved at both the national and the international level. The tense negotiations on the distribution (allocation) of fishing opportunities between states illustrate how difficult this already is. Resolving conflicts between different uses of the marine environment is first of all a matter of the national sphere, even though the LOS Convention has provided a framework by distributing jurisdiction in a geographical and substantive sense. Where states have to decide between conflicting uses of their oceans, it can be helpful to define the various goods and services of ecosystems ${ }^{174}$ in economic terms. In relation to marine mammal-fishery interactions, this could for instance involve weighing the direct and indirect economic impact of marine mammals on fisheries and the value of hunting marine mammals as a resource against the non-lethal uses of marine mammals such as whale-watching or the knowledge that marine mammals are left undisturbed. To quantify this last aspect in economic terms is a challenging task but a necessary one to ensure that societies are fully aware of the way in which they are giving effective content to sustainable development. ${ }^{175}$ Where marine mammals are protected at the cost of commercial fisheries, this could be resolved by compensation schemes. ${ }^{176}$

Science can offer states little help in making these choices. Apart from identifying minimum standards or sizes to avoid extinction or over-exploitation, there simply is no ideal ecological balance or ideal population size for species. Management objectives are therefore bound to be subjective and thereby open to criticism. ${ }^{177}$ The

174 The NRC Report (1999), note 66 above, p. 1 defines these as "ecosystem products and processes that directly benefit humans. They include food, breathable air, clean water, fiber, medicines, quality of life, and many other items."

175 See also FAO Doc. RFB/II/2001/7, note 85 above, at para. 50 .

176 See the Finnish efforts in note 14 above in this respect.

177 See, inter alia, D.S. Butterworth and A.E. Punt, note 142 above, p. 7; and the DFO Report (2001), note 142 above, pp. vi-viii. 
role of law is in that respect also limited, perhaps merely one of facilitating conflict resolution and decision-making processes. ${ }^{178}$ Ecosystems are in a constant state of flux, even before human impact became noticeable. These changes can be irreversible, for instance due to long-term "survival of the fittest" processes, but can also be cyclical on the short or intermediate term. This brings us once again to the role of humans on earth. The matter is clearly not just if humans have the right to kill other living beings but also if we have a right or duty to model ecosystems. As regards the latter point, it is unrealistic that humans will ever collectively adopt a strict policy of avoiding any direct interference with nature, especially in the face of tragedies. If they would, this would not prevent indirect interference anyway. As already mentioned before, the choices inherent in tailoring ecosystems are not easy and, in view of the limitations of science, success is certainly not guaranteed. The growing interest in ecosystem and EBFM approaches will hopefully lead to greater awareness of and respect for the complexity and functioning of ecosystems and thereby maximise the chance for successes.

\section{Conclusions}

In the not so distant future, the general public and the international community of states will have to come to terms with the fact that many species of marine mammals are no longer under threat of extinction. This awareness is expected to evolve as a consequence of the likely further deterioration of global fish stocks, the widening support for ecosystem-based fisheries management (EBFM) and the associated recognition of the interactions between marine mammals and commercial fisheries. These interactions will then no longer mainly focus on bycatch of marine mammals but will more and more frequently also be approached from the perspective of the commercial fishing industry. The related perception that there is in fact no fundamental distinction between marine mammals and other forms of life may also be a contributing factor. ${ }^{179}$ As a consequence, the preferential status now enjoyed by marine mammals in the form of bans on hunting is likely to gradually erode towards treating them as not fundamentally different from other renewable natural resources. As many exotic species are now available in restaurants and shops in many parts of the world, for instance kangaroo or ostrich, is it really so difficult to imagine eating seals or whales? True, such changes in mindset would have been difficult to conceive two decades ago but since then the mindset's underlying rationale has evaporated. All this does not exclude a gradually expanding body of national and international law on humane treatment of animals, including killing methods.

It is worth emphasising, however, that human activities are the main, if not

${ }^{178}$ In contrast, the legal notion of equitability would be particularly relevant to the allocation of fishing opportunities between stakeholders. See e.g. para. 30(e) of the WSSD Plan of Implementation.

${ }^{179}$ See the opinion polls cited by W. Aron, et al., note 4 above, p. 189. 
only, reason for the current state of world fisheries and that marine mammals cannot be scapegoats for human failure. Nevertheless, even though the usefulness of EBFM as a predictive management tool may still be far ahead, the fact that marine mammals (may) have an impact on commercial fisheries cannot be ignored. Unless or until such time that marine mammals are exploited as a resource per se and not just wastefully culled as a pest, sufficient scientific research will be needed to substantiate the positive effects that pre-emptive catches of marine mammals would have for commercial fisheries.

Under current general international law, the decision to exploit marine mammals or not is to a large extent up to individual states in view of what they perceive as "necessary" in their own interests, without disregarding more superior obligations such as the duty to avoid over-exploitation, to co-operate and to prevent species from becoming extinct. Quantifying ecosystem goods and services in economic terms may help to ensure that societies are fully aware of what they regard as "necessary" and thereby how they give effective content to the objective of sustainable development. For instance: more marine mammals instead of more commercial fisheries or vice versa. It can moreover be argued that under certain circumstances exploitation of marine mammals by means of pre-emptive catches may not just be necessary but in fact obligatory. This would arise in a situation where marine mammals dominate ecosystems to the extent that other (populations of) species are under threat of extinction, either due to predation or due to side effects. Less straightforward is the situation in which large numbers of marine mammals cause severe transboundary effects to ecosystems or living resources in the maritime zones of other states, or on the high seas. In particular in the first situation, the application of the precautionary approach may trigger or enlarge such catches.

If EBFM is perceived as a holistic approach to fisheries management, current international instruments relevant to fisheries management and conservation do not oblige states or regional fisheries management organisations to pursue EBFM. However, the adoption of several relevant instruments in the $1990 \mathrm{~s}$, such as the 1995 Fish Stocks Agreement and the 1995 FAO Code of Conduct, as well as the experience under the CCAMLR Convention, show that a gradually broadening range of ecosystem considerations must or should be taken into account in fisheries management. The 2001 Reykjavik Declaration on Responsible Fisheries in the Marine Ecosystem supports this latter view. Even if a holistic EBFM approach is seen as legally mandatory now already or as becoming so in the near future, in view of the limitations of science and the geographical, budgetary and cost-effectiveness implications, states and international organisations would have considerable discretion to pursue it only "as far as practicable". The level of EBFM that is currently achieved under the CCAMLR Convention will not be available to most fisheries management authorities in the immediate future for a number of reasons. These include the relatively modest fishing effort (and profits) and the importance attributed to conducting marine scientific research within the framework of the Antarctic 
Treaty System. However, the efforts on Baltic 21 in the Baltic Sea Area illustrate that ecosystem approaches are perceived as necessary and in the states' own interests. The limited predictive potential of a holistic EBFM approach nevertheless calls for modest expectations about the ability to tailor ecosystems, quite apart from the difficult questions it raises on the role of humans on earth.

As a concluding remark, it is submitted that the only reason for prohibiting the exploitation of marine mammals that the entire community of states currently supports is a threat of over-exploitation and extinction of species. In view of the appalling conservation history and the particular vulnerability of most marine mammals, however, hunting should always be science-based, with a strong emphasis on the precautionary approach, risk assessment and other guarantees, such as a reliable enforcement framework in its broadest sense. ${ }^{180}$ Without these, a rehearsal of past tragedies is inevitable.

${ }^{180}$ Efforts should also be directed at ensuring that marine mammals do not "unnecessarily" suffer from hunting. 